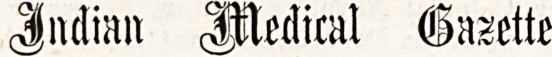

DECEMBER.
THE END OF THE WAR AND LEAVE.

THE news of the cessation of hostilities and of the approaching end of the Great War was the great event of November 1918, and amid the general thankfulness and rejoicing at our Empire having come out strong and victorious in the great battle for Right, to a good many thequestion has already arisen,-Can I get leave or when can I get leave? The query is natural. Even before the war the leave question in the Indian Medical Service had become an acute one; the war ended all grumbling, though it found many men with months and years of furlough earned and due. The question, therefore, must now arise and must be settled.

There are several categories of men who need leave. First those whose names are shown in italics, 24 in all, in the Army List, men who have done their full service and are only detained for the period of the war. Then there are the men recalled from pension and re-employed; they will claim to go back. Then we have the men who for four anxious years have literally borne the heat and burden of the day in France, Egypt, and in Mesopotamia. No one doubts their great need and right to leave. Then come the men who had not the luck to go to the Front, but who remained in indispensable billets, often doing two or three men's work- "carrying on " and doing their duty ably and well. All these classes need leave, and it must be arranged, or the Service will break down.

The leave rules themselves are liberal, but the difficulty has been that few were ever able to avail themselves of them. Some could not be spared, many could not afford it (for to junior men almost always leave Home meant running into debt).

There is only one way in which the rightful claims of all can early be satisfied. That is to temporarily limit the duration of all leave (except sick) to 7 or 8 months; and give full pay for the whole period (i.e., privilege leave up to 4 months and commuted leave for 3 or 4 more). Everyone has abundance of furlough earned, and all will gladly give up 6 months' furlough for 3 months' full-pay leave. Let the men who have been to the various fronts, get privilege leave up to 6 or even 8 months; why not? If such a scheme was set in motion the turn for leave would come round quickly to all. In the course of less than three years the majority of men would have had their leave and the old conditions (amended as already contemplated) could come into force again. This is an urgent matter, and we see no other possible way of giving men their rights with due regard to their duties, and with similar due regard to the claims of so many others.

\section{MEDICAL STUDENTS AND THE WAR}

RETURNS have now been submitted by the General Medical Council to the Ministry of National Service, which show the actual number of medical students in the United Kingdom.

It is clear that third and fourth-year students are well below the average needed. There has been a substantial improvement in the junior years. The following figures show the differences :-

$\begin{array}{lll}\text { May } 1916 & \ldots & \ldots \\ \text { January } 1917 & \ldots & \ldots, 103 \\ \text { October } 1917 & \ldots & \ldots 7,682 \\ \text { May } 1918 & \ldots & \ldots 7,048 \\ \end{array}$

It is worth noting that no less than 33 per cent. of all medical students are women (England 36 per cent., Scotland 36 per cent., and Ireland 10 per cent.).

In the beginning of 1918 there were on the Medical Register 43,819 names, of whom 23,715 belonged to England, 13,918 to Scotland, and 6,176 to Ireland.

It is certain that there will be a marked shortage of medical men becoming qualified in the years 1919 to 1921 , and it is very clear that such shortage will seriously affect recruiting for the I. M. S. and other public services, and will have to be met by a handsome increase in the pay terms offered.

\section{Qurrent đopiqus.}

THE BUST OF SIR LEONARD ROGERS.

A PLEaSant function took place on Monday, 19th November, 1918, at the Calcutta School of Tropical Medicine, when His Excellency the 